УДК 69

DOI 10.21661/r-552940

\title{
М.А. Чижова
}

Характерные неисправности гидросистемы

и способы их устранения в ограниченных условиях

\section{Аннотация}

В статье рассматриваются некоторые из возникающих неисправностей при работе гидросистемы на лесозаготовительных машинах. В ходе анализа неисправностей и практического опыта, предлагаются варианты устранения на месте или минимальный ремонт для обеспечения транспортировки в ремонтные боксы.

Ключевые слова: гидравлика, система, отказ внезапный, отказ постепенный, нагрев, деформация, работоспособность, поломка, устранение неисправности, воздушные фильтры, резиновые кольца под ракушками, шланги высоко давления, стандартный набор инструментов, гидрораспределитель, форвардер.

\section{M.A. Chizhova \\ Characteristic Malfunctions of Hydraulic System and Methods of its Elimination Under Restricted Conditions}

\section{Abstract}

The article discusses some of the problems that occur during the operation of the hydraulic system on logging machines. In the course of fault analysis and practical experience, options for on-site remediation or minimal repairs are suggested to ensure transport to the repair boxes.

Keywords: hydraulics, system, sudden failure, gradual failure, heating, deformation, operability, breakdown, troubleshooting, air filters, rubber rings under shells, high pressure hoses, standard tool kit, hydraulic distributor, forwarder.

$\mathrm{O}$ сновной задачей было обратить внимание на возникающие неисправности лесозаготовительной техники, использующейся в сложных погодных условиях. Техника рассматривалась компании «Понссе», в тесном сотрудничестве с механиками, работающими на данных машинах Форвардеры компании «Понссе» оснащены двигателями Mercedes-Benz модели MWOM 906LA. Это шестицилиндровый четырехтактный двигатель с турбонаддувом, мощностью 180 кВт и крутящим моментом $900 \mathrm{H}$ м при частоте вращения коленчатого вала $1200 \ldots 1600$ мин-1. Двигатель имеет водяное охлаждение и отвечает всем требованиям стандарта EUROMOT/EPA 2.

Передача крутящего момента от двигателя к ведущим органам форвардера может быть реализована через следующие виды трансмиссий: механическую, гидростатическую, механогидростатическую и механо-гидродинамическую.

В рассматриваемых типах и марках форвардеров используется механо-гидростатическая трансмиссия с двухдиапазонной коробкой передач. Такая трансмис- сия включает в себя три основные составные части: механическую, гидравлическую и электрическую. В состав механической части входят раздаточная коробка, карданные валы и тандемные тележки.

Гидравлическая часть состоит из гидромотора, подсоединенного к раздаточной коробке, и гидронасоса, присоединенного к двигателю. Гидронасос и гидромотор образуют замкнутый контур, в котором рабочая жидкость, поступающая из насоса в гидромотор, возвращается обратно в него. И насос, и гидромотор представляют собой устройство аксиально-поршневого типа с переменной производительностью. Кроме управления электромагнитными клапанами, поток рабочей жидкости, нагнетаемой насосом, можно изменить за счет изменения частоты вращения коленчатого вала двигателя. Направление и частота вращения вала гидромотора зависят от направления и величины потока рабочей жидкости, нагнетаемой гидронасосом. Раздаточная коробка расположена в задней части передней полурамы. Крутящий момент, создаваемый гидромотором, передается через раздаточную коробку с 
помощью карданных валов на дифференциалы переднего и заднего мостов. Переключение передач производится на правом пульте управления в кабине оператора. Переключатель управляет работой гидроцилиндра переключения передач с помощью электромагнитного клапана. В гидравлической системе, как и в любых другой, встречаются два вида неисправностей: внезапные и постепенные.

Внезапные отказы - это резкие, скачкообразные изменения значений одного или нескольких основных параметров устройства (например, заклинивание подвижных частей, разрушение или деформация деталей гидрооборудования). При внезапных отказах гидросистема теряет свою работоспособность.

Также встречаются, постепенные отказы - это медленное постепенное изменение значений одного или нескольких основных параметров устройства (например, снижение мощности двигателя ниже установленной), являющееся следствием естественного износа деталей, нарушения герметичности или неправильной установки гидроаппаратуры. Постепенные отказы ведут к медленной потере работоспособности, когда гидросистема может еще работать, но все менее эффективно, с меньшей производительностью, с нерациональными затратами энергии.

Помимо этого, может произойти, так называемый, независимый отказ - это отказ отдельного элемента гидропривода, не обусловленный повреждениями других элементов (например, поломка пружины гидрораспределителя). Отказ, возникший в результате повреждения или выхода из строя других элементов, называется зависимым отказом (например, заклинивание золотника распределителя вследствие выхода из строя напорного фильтра). Возможны случаи, когда однах и та же неисправность (например, насоса) может привести к функциональной неполадке и в машине (снизив производительность), и в гидросистеме (повысив уровень шума). Опыт показал, что поиск неисправностей предпочтительно начинать с основных проблем и прорабатывать тестовые процедуры, учитывая такие признаки, как повышение температуры, шума, утечки.

Можно ли определить неисправность гидросистемы в ограниченных условиях со стандартным набором инструментов? В данной ситуации, не имея приборов для выявления неполадок, простейшие неисправности гидравлической системы можно определить с помощью органов чувств - увидев, ощутив, услышав, причем достаточно легко. На практике многие проблемы решаются именно таким способом. Например, можно увидеть подтекание рабочей жидкости в местах соединений элементов, этому может послужить слабая затяжка резьбовых соединений или разрушение уплотнительных элементов, данная поломка относится к постепенным отказам гидросистемы, так как в дальнейшем может привести к более серьёзным поломкам. А также, можно услышать не характерный шум при работе насоса, причиной такого шума, может являться износ приводных редукторов и муфт, данная проблема больше относится к внезапному отказу гидросистемы, так как данная поломка относится к деформации гидрооборудования, в результате чего, гидросистема может потерять свою работоспособность. Помимо этого, достаточно просто можно ощутить нагрев на корпусе гидрораспределителя и прилегающих к нему трубопроводах слива рабочей жидкости, что может означать неисправность клапанов ли износ золотников гидрораспределителя, что тоже является внезапным отказом гидросистемы.

В результате сбора информации был проведен опрос среди машинистов лесозаготовительной техники форвардера ponsse elephant. Им было задано три вопроса. Первый вопрос, самая частая поломка гидросистемы? Второй вопрос, что является причиной данной поломки в гидросистеме? И заключительный вопрос - можно ли решить данную проблему в ограниченных условиях, подручными средствами.

По итогам опроса, помимо замены манжетных колец, гидравлических и воздушных фильтров, резиновых колец под ракушками, замены USIT-R и переходников со шланга на ротатор, самой частой поломкой гидросистемы, является выход из строя шланга высокого давления. Причин данной поломки может быть несколько: фитинг на шланге не выдерживает высокого давления и вследствие чего начинает пропускать масло, а также, сам шланг может лопнуть или протереться о броню форвардера. Так как, выход из строя шланга высоко давления является достаточно частой причиной поломки гидросистемы, для того чтобы решить проблему на месте, водители заранее приобретают шланги высоко давления, а для замены, используется стандартный набор инструментов. Помимо этого, каждый водитель ссылался на высокую производительность и отличную «живучесть» техники, в тяжелых условиях.

Таким образом, ремонт гидравлической системы в ограниченных условиях, чаще всего сопровождается устранением достаточно простых поломок, например, при подтекании масла, нужно сильнее затянуть резьбовые соединения, если резьбовое соединение имеет дефект, при затягивании, можно использовать герметик, для более плотного и герметичного соединения. Так же, более глобальные проблемы, которые на первый взгляд, в ограниченных условиях не решить, можно устранить достаточно простыми действиями. Например, неравномерное движение рабочих органов, может вызвать малое противодавление на сливе из цилиндра, решить данную проблему можно повысив сопротивление на сливе, с помощью регулировки дросселя или подпорного клапана. А также, поломка может быть вызвана неравномерной подачей масла насосом, данную проблему можно решить заменой насоса, что в ограниченных условиях невозможно. Поэтому, решение проблем и устранение поломок в ограниченных условиях, зависят от опыта, находчивости и квалификации рабочего. 


\section{Литература}

1. Абрамов Е.И. Элементы гидропривода: справочник / Е.И. Абрамов, К.А. Колесниченко, В.Т. Маслов. - 2-е изд., перераб. - Киев: Техника, 1977.

2. Хорош А.И. Гидрооборудование лесных машин: учебное пособие для студентов специальности машины и оборудование лесного комплекса всех форм обучения. Часть 1 / А. И. Хорош. - Красноярск: Изд-во СибГТУ, 2009. - 280 с.

\section{References}

1. Abramov, E. I., Kolesnichenko, K. A., \& Maslov, V. T. (1977). Elementy gidroprivoda: spravochnik. Kiev: Tekhnika.

2. Khorosh, A. I. (2009). Gidrooborudovanie lesnykh mashin: uchebnoe posobie dlia studentov spetsial'nosti mashiny i oborudovanie lesnogo kompleksa vsekh form obucheniia. Chast' 1., 280. Krasnoiarsk: Izd-vo SibGTU. 